\title{
Influence of the Tibetan Plateau uplift on the Asian monsoon-arid environment evolution
}

\author{
LIU XiaoDong ${ }^{1,2^{*}} \&$ DONG BuWen ${ }^{3}$ \\ ${ }^{1}$ State Key Laboratory of Loess and Quaternary Geology, Institute of Earth Environment, Chinese Academy of Sciences, Xi'an 710075, China; \\ ${ }^{2}$ School of Human Settlements and Civil Engineering, Xi'an Jiaotong University, Xi'an 710049, China; \\ ${ }^{3}$ National Centre for Atmospheric Science, University of Reading, Reading, RG6 6BB, UK
}

Received November 23, 2012; accepted April 28, 2013; published online July 23, 2013

\begin{abstract}
As one of the most important geological events in Cenozoic era, the uplift of the Tibetan Plateau (TP) has had profound influences on the Asian and global climate and environment evolution. During the past four decades, many scholars from China and abroad have studied climatic and environmental effects of the TP uplift by using a variety of geological records and paleoclimate numerical simulations. The existing research results enrich our understanding of the mechanisms of Asian monsoon changes and interior aridification, but so far there are still a lot of issues that need to be thought deeply and investigated further. This paper attempts to review the research on the influence of the TP uplift on the Asian monsoon-arid environment, summarize three types of numerical simulations including bulk-plateau uplift, phased uplift and sub-regional uplift, and especially to analyze regional differences in responses of climate and environment to different forms of tectonic uplifts. From previous modeling results, the land-sea distribution and the Himalayan uplift may have a large effect in the establishment and development of the South Asian monsoon. However, the formation and evolution of the monsoon in northern East Asia, the intensified dryness north of the TP and enhanced Asian dust cycle may be more closely related to the uplift of the main body, especially the northern part of the TP. In this review, we also discuss relative roles of the TP uplift and other impact factors, origins of the South Asian monsoon and East Asian monsoon, feedback effects and nonlinear responses of climatic and environmental changes to the plateau uplift. Finally, we make comparisons between numerical simulations and geological records, discuss their uncertainties, and highlight some problems worthy of further studying.
\end{abstract}

Tibetan Plateau, tectonic uplift, Asian monsoon, inland aridity, environmental evolution, geological record, numerical simulation

Citation: Liu X D, Dong B W. Influence of the Tibetan Plateau uplift on the Asian monsoon-arid environment evolution. Chin Sci Bull, 2013, 58: 4277-4291, doi: $10.1007 / \mathrm{s} 11434-013-5987-8$

The Tibetan Plateau (TP), with an average altitude of over $4000 \mathrm{~m}$ and an area of $2500000 \mathrm{~km}^{2}$, is a product of the collision of northward-drifting India-Australia plate with the Eurasian plate [1,2]. The TP uplift was the most dramatic tectonic event during the recent geological history of the solid Earth evolution and has been considered as an important driving force for the Earth's climate and environmental change. It has not only changed the landscape and natural environments within the TP region, but also had a

*Corresponding author (email: liuxd@loess.llqg.ac.cn) profound impact on the Asian monsoon, inland aridification and global climate change during the Cenozoic.

During the past four decades, many scholars in China and abroad have studied the influence of the TP uplift on the Asian monsoon-arid environment evolution through geological records and numerical simulations of paleoclimate, and have made considerable progress in understanding the climatic and environmental effects of plateau uplift. Up to now, plenty of geological evidence has supported that the TP uplift is closely related to the formation and development of the Asian monsoon and inland aridification (e.g. 
[3-5]), but there has been no consensus on the history and forms of plateau uplift, as well as the origin and regional differences of the Asian monsoon and inland aridification (e.g. [6-8]). With respect to modeling study, increasinglysophisticated numerical experiments, from the bulk-plateau uplift experiment in the past to recent phased uplift and sub-regional uplift experiments (e.g. [9-12]), have greatly deepened our understanding of the influence of plateau uplift forms on the climate change in different Asian regions and underlying mechanisms. However, due to a number of uncertainties in recognizing various feedback effects, the nonlinear response of climatic and environmental changes to the uplift, and scale superimposition and multi-factor comprehensive effects and so on during the uplift process, there are a number of problems worthy of further study and discussion, and new problems are emerging constantly.

This paper attempts to review the research on relationship between the TP uplift and Asian monsoon-arid environment evolution, to analyze and summarize the impact and its regional differences of different forms of tectonic uplifts on the evolution of the Asian monsoon, and finally to put forward some ideas on further study in this field.

\section{Outline of research on climatic and environ- mental effects of the Tibetan Plateau uplift}

\subsection{Geological records}

At present, the geological evidence for the TP uplift comes from a wide range of sources (see [1,2,13-15] for overview), including the lithosphere tectonics and magmatism, crustal thickening and deformation, cooling event of rock, stable isotope-based paleoaltimetry, environment change records and so on. Although our understanding has been deepening with continuous accumulation of evidence, so far no unified view has been reached about the history of the TP uplift due to the complexity of the problem itself. In the 1960s and 1970s Chinese scholars suggested that the Pliocene could be the major period of the TP uplift based on studies of paleontology, paleovegetation, geomorphy and geological tectonics (e.g. [16-18]). Subsequent evidence indicated that the TP had already uplifted and reached a considerable height prior to the Pliocene. For instance, the Yangbajing graben northwest of Lhasa [19], vegetation succession from forest to grassland in northern Pakistan [20] and enhanced upwelling current on the Arabian Sea coast [21] were all recognized as important evidence for the TP uplift during the late Miocene, and some scholars believed that the TP could have reached its full height around $8 \mathrm{Ma}$ [19]. Afterwards some researchers speculated that the TP had basically reached its maximum height in the middle Miocene (14-15 Ma), and then changed little or even declined slightly according to research on the timing of Himalayan normal fault activity [22] and fossil leaves of paleoplants in southern Tibet [23]. Recently some scholars, based upon magnetic stratigraphy and sedimentology studies of basins in the central and northern TP [24] and the oxygen isotope data of basins in the central TP [25], recognized that the central TP could have reached its current height in the middle and late Eocene (40-35 Ma).

In the research of long-term evolution of Asian paleoenvironment since the Cenozoic, understanding of causes for the formation and development of the Asian monsoon environment and inland aridification has drawn much attention. Many scholars in China and abroad have studied changes of two sub-systems of the Asian monsoon-the East Asian monsoon and South Asian monsoon (the latter being the Indian monsoon) in a variety of timescales (see [26-29] for a comprehensive introduction) by using various geological records including loess, lakes, deserts, glaciers, organisms and marine sediments. As one of excellent paleoenvironmental archives, Chinese loess fully and accurately recorded the historical alternation of the predominant periods of the East Asia winter monsoon and summer monsoon during the past 2.6 Ma with Quaternary loess-paleosol cycles [27]. The discovery and research of the Neogene eolian red clay underlying the Quaternary loess further broadened the record of the East Asian monsoon evolution on a long timescale $[4,27,30,31]$. It was generally believed that marine sediments of the Arabian Sea and Indian Ocean and continental sediments of the South Asian subcontinent [29] better recorded the evolution of the South Asian monsoon during geological period, but recently different views and new explanations [32] were proposed for the records of upwelling in the Arabian Sea [21] and paleovegetation changes in South Asia [20]. Meanwhile, the eolian deposition also recorded the long-term process of aridification in inland Asia. The oldest eolian loess found in northern China appeared in the early Miocene (22-25 Ma) [4,33,34], a critical period around which the environment transformed from a planetary circulation system into a monsoon-dominated pattern, as indicated by integrated studies of Asian paleoenvironmental records [35-37]. Both continental [38] and marine [39] eolian deposition records showed that aridification of inland Asia was significantly intensified during recent 3-4 Ma since the Pliocene.

In the study of the relationship between the plateau uplift and environmental change, their possible connections were often speculated based on the simultaneity of tectonic uplift and environmental change. For example, the climate changes in Asia during the late Miocene shown by some marine and continental records $[2,3,7,19,39-42]$ were usually considered as the result of strong TP uplift at the same time. The results of some studies also showed that during the middle and late Pliocene there were remarkable tectonic uplifts in the northern TP, which led to the intensification of the Asian monsoon and significantly increased variability of monsoon since Quaternary [3]. However, the late Miocene and middle Pliocene were also critical periods for global climate change, especially for the cooling of the northern hemisphere; the cooling had an obvious influence on Asian 
climate as well. Some recent geological and environmental records showed that large-scale uplifts might have occurred as early as the Eocene in some areas of the TP [24,25]. Studies on long-term eolian records [4,39] and the transition of Asian paleoenvironmental patterns [35-37] suggested that dramatic changes in the Asian monsoon and inland arid environment could have taken place during the early Miocene or late Oligocene. It can be seen from the above statements that at present it may be too early to systematically compare the evidence of the TP uplift during the Cenozoic and the evidence of environmental changes in Asia from a perspective of time. Thus, it is not enough to infer a causeeffect relationship between them only from the geological evidence of tectonic uplift-environmental change, and more analyses of mechanisms with numerical simulations are needed. Currently much attention has been paid to the numerical simulations of paleoclimate, which have greatly promoted the research on influence of the TP uplift upon the Asian monsoon-arid environment evolution.

\subsection{Numerical simulations}

In the past four decades, with the continuous development of the theory of geophysical fluid dynamics, numerical methods and computer sciences, the use of numerical simulation with three-dimensional global climate models has become an effective method to analyze, examine and develop paleoclimate dynamics theories. Domestic and foreign scholars have used state-of-the-art numerical models (including general circulation models, coupled ocean-atmosphere models, and coupled ocean-land-atmosphere-ice earth system models) to explore effects of the TP uplift in Asian and global climate evolution by changing the height of topography. These modeling results have confirmed that the TP uplift and Asian climate change have a clear cause-effect relationship although there are some differences in the results of various studies.

The existing numerical experiments on climate effects of the TP uplift can be broadly classified into three categories: (1) bulk plateau uplift experiment, which implements the simple "full mountain"/"no-mountain" experiments to highlight the contribution of plateau topography to atmospheric circulation and climate; (2) plateau phased uplift experiment, in which the uplift is divided into different stages and effects of progressive uplift are examined systematically according to a certain proportion of the modern height; and (3) plateau regional uplift experiment, in which each sub-regional uplift is considered separately and its influence on the climatic subsystems in different regions is investigated. In addition, in the paleoclimate simulations of specific geological periods (such as the Eocene, Oligocene, Miocene, and Pliocene), paleogeographical and paleotopographical boundary conditions reconstructed with geological evidence were prescribed to study the influence of plateau topography on climate and environment. Following is an overview of repre- sentative works in each category.

More than half a century ago meteorologists showed interests in dynamic and thermal effects of the TP on atmospheric circulation [43-45]. In the 1960s and 1970s, early General Circulation Models (GCMs) were successfully applied in studies on atmospheric circulation and climate under the conditions with and without topographic features [46-49]. Manabe et al. [48,49] systematically revealed the importance of presence of plateau topography in the development of the South Asian monsoon. They conducted comparative experiments of full-mountain and no-mountain scenarios by using a GCM and found that the TP topography not only decided the location and intensity of the Siberian High, a core system of the Asian winter monsoon, but also controlled the establishment and development of the South Asian summer monsoon. The TP uplift significantly enhanced the plateau heating source in late spring and early summer, therefore strengthened the thermal contrast between the Asian continent and the Indian Ocean, and thus the Asian summer monsoon circulation. However, resolutions of earlier GCMs were generally low, physical processes of the models were comparatively simple, and therefore these models did not simulate the present-day climate well in comparison with the observation. Additionally, the dynamical and thermal effects were not distinguished in these earlier modeling studies.

In the following decade or so, GCMs were improved in both their resolutions and physical parameterizations. It became necessary to reevaluate the effects of the TP uplift on atmospheric circulation, monsoonal climate and arid environment by using these improved numerical models. Therefore, a number of scholars explored the impacts of the TP topography on atmospheric circulation and climate change from different perspectives. In China, Qian et al. [50] initiated numerical modeling studies of large-scale topographic effects of the TP on atmospheric circulation and revealed the importance of the TP's dynamical and thermal effects in the formation of Asian regional circulation and development of the Asian monsoon. Internationally, Kutzbach et al. [9,51,52] explored the impacts of the TP and Rocky Mountains in North America on regional and global climate and environment by conducting sensitivity experiments with full-mountain, half-mountain and no-mountain as well as comparing their modeling results with the geological evidence of the tectonic uplift and climate change. They found that the TP uplift enhanced summer heating and winter cooling effects over the plateau, amplified the seasonal contrast, and intensified the seasonal transition of the prevailing wind, thus significantly enhanced the Asian winter and summer monsoons [52]. Meantime, the descending current caused by the topography-induced stationary wave, dynamic overflow over mountain and split flow around mountain, the compensatory subsidence of air outside the TP in response to the ascent due to the plateau summer heating and moisture barrier effect of the topography all contributed to 
the aridification of Asian inland [9,53-56]. Therefore, the TP uplift caused regional differences in climate responses: the eastern and southern plateau became wetter and the western and northern part became drier. The most direct effect of the TP uplift on temperature change at regional scale was the reduction of surface air temperature in the uplift region due to the lapse rate effect. In addition, the TP uplift had remote effects on climatic and environmental changes. At the hemispheric scale, the effect of the TP uplift was propagated to remote regions through modulating the stationary planetary wave of northern hemisphere. At the global scale, the plateau uplift could also cause global cooling through feedback mechanisms such as reducing the atmospheric $\mathrm{CO}_{2}$ concentration by weathering and erosion [57] and other feedback mechanisms. These simulation results, to a certain extent, were in accordance with the geological evidence of the tectonic uplift and environmental change [52], thus deepening the understanding of the relationship between the plateau uplift, and regional as well as global climatic and environmental changes.

In some studies more realistic paleogeographical, paleotopographical and other lower boundary conditions were prescribed in numerical models to simulate paleoclimates during specific geological periods (such as the Eocene, Oligocene, Miocene or Pliocene), especially on the Asian monsoon climate change. For example, in the climate simulation of the Eocene (45-33 Ma) [58], the maximum height of the TP was set at 2000-4000 m and corresponding average topographic height was set at about only $750-1500 \mathrm{~m}$. This simulation revealed remarkable impacts of the TP topographic change on its neighboring regional climate, but also demonstrated that the plateau topographic reduction during the Eocene had limited impacts on the existing global monsoon and precipitation at that time. Ramstein et al. [59] simulated the climate in the early Oligocene ( $30 \mathrm{Ma})$ when the Paratethys Sea occupied many areas of western Asia to central Asia while limited uplift occurred only in the southern TP. Their results showed that the expansion of Eurasian land area with the retreat of the Paratethys Sea from the early Oligocene to the late Miocene significantly enhanced the Asian monsoon and precipitation. The recent study by Zhang et al. [60] further concluded that the change in land-sea distribution due to the Paratethys Sea retreat had similar influences on the Asian monsoon and inland aridification as the plateau uplift. However, these studies failed to quantitatively determine relative contributions of the TP uplift and Paratethys Sea retreat to the enhanced Asian monsoon, and thus further quantitative studies are needed to highlight their relative importance. A climate simulation of the middle Miocene (20-14 Ma) [61,62] showed that the relatively low topography at that time had certain contribution to the formation of climatic optimum period, but the effects of elevated atmospheric $\mathrm{CO}_{2}$ concentration and other factors such as feedbacks of ocean and land were also necessary. In the simulation of the late Miocene (11-5 Ma) with the TP topography being set as a half [63] or 70\% [64] of its current height, the feature of the overall weak Asia summer monsoon was observed. In the Pliocene $(\sim 3 \mathrm{Ma})$, a period closer to modern time, certain degree of changes in the plateau topography was still considered in the climate simulation [65]. In general, in paleoclimate simulations regarding the past specific geological periods, the influence of the overall change in the TP topography on the Asian monsoon-arid environment was qualitatively similar to the findings in the previous idealized sensitivity experiments. It should be pointed out that a successful paleoclimate modeling for a specific geological period often depends on the geological evidence used as the lower boundary conditions at that time. Considering the fact that at present the geological evidence from different sources still has much space for improvement in consistency, we believe that the value of the numerical simulations on the climate effect of the plateau uplift is better reflected in the understanding of mechanisms of climate change, while accurate reproductions of climatic features for specific geological periods should not be excessively expected. Paleoclimate modeling for specific geological periods needs to be gradually improved through continuous accumulation and research of the geological records.

The comparison of experiments with and without topography or experiments with high and low topography could directly demonstrate the effects of plateau in the formation and changes of regional and even global climate. However, the bulk plateau uplift might differ from geological facts. Plenty of geological evidence [3,14,19,66-69] was more likely to suggest that the formation of the TP experienced multi-stage processes of uplift. In order to explore the condition closer to the geological facts, some scholars specifically designed numerical experiments with various GCMs to examine the influence of phased plateau uplift on the Asian climate. An et al. [3] completed numerical simulations of four idealized stages of the TP uplift and revealed that the topographic uplift and Asian monsoon climate had a phase-coupling relationship in the past $8 \mathrm{Ma}$. The accelerated uplift of the plateau, especially the northeastward expansion of the TP could enhance the East Asian winter and summer monsoons simultaneously, and intensify the aridification of inland Asia. Liu and Yin [10] conducted a series of numerical experiments with an interval of $10 \%$ of the current TP height to assess roles of the phased plateau uplift in 11 stages of the formation and evolution of the Asian monsoon. The results indicated that with regarding to the seasonal change in the direction of winter and summer prevailing winds, the East Asian monsoon was more sensitive to the TP uplift than the South Asian monsoon, and the plateau uplift had much greater impacts on the East Asian winter monsoon than the East Asian summer monsoon. With the gradual uplift of the TP, the temperature contrast between winter and summer increased continuously in the East Asian monsoon region, and the precipitation became more concentrated in summer. From the perspective of temperature 
and humidity conditions, the intensity of northern East Asian monsoon north of the Yangtze River increased almost linearly in response to the increase of topographic height, but the southern East Asian monsoon south of the Yangtze River and Indian monsoon varied nonlinearly with the plateau uplift. The response of inland aridification to the TP growth was also nonlinear, the reduction of inland soil moisture was greater in late stages than that in early stages of the plateau uplift with the same height increase. Afterwards, Abe et al. [70] conducted phased uplift experiment with a coupled ocean-atmosphere model at intervals of $20 \%$ of current TP height and their results indicated that the TP uplift impacted sea surface temperatures, which in turn modulated the Asian monsoon as a feedback.

Although the numerical experiments of the TP phased uplift were theoretically closer to geological facts than those of the bulk uplift, the design of the lower boundary conditions for experiments with idealized stepwise uplift of the plateau might still be too simplified in comparison to the real geological history. New geological evidences [14,67,71,72] were more likely to support the asynchronous uplift in different regions of the TP. Namely, the rate and amplitude of the uplift might vary in different sub-regions of the plateau. The asynchronous uplift or different forms of vertical and horizontal growth in different sub-regions of the plateau could cause varied climatic and environmental effects to different surrounding regions. Therefore it seemed necessary to conduct numerical experiments of the plateau subregional uplifts and to assess their climatic impacts.

\section{Forms of tectonic uplift and regional differences of the Asian climate evolution}

An increasing amount of geological evidence showed that since the collision of Indian subcontinent and the Eurasian plate [1], the TP might not synchronously uplift as a whole, but uplifted gradually and separately in different sub-regions. According to the difference in the eruption time of the high$\mathrm{K}$ lava in the west and east regions of the Qiangtang Plateau, Chung et al. [71] suggested that different locations of the TP had various uplift history. Based on the oblique subduction of continental lithosphere, Tapponnier et al. [67] proposed a multi-stage uplift model where the TP uplifted subregionally, gradually advancing from south to north. The southern plateau uplift including the Himalayas commenced in the Eocene; the central plateau uplift occurred during the period from the Oligocene to Miocene; and the northern plateau uplifted relatively late, during the period of the Pliocene to Quaternary. Zhong and Ding [66], based on fission track dating of Zircon and apatite in the eastern Himalayan syntax, deduced that the TP uplift was a multi-stage and asynchronous process. Some studies also suggested that the central TP had reached its current height as early as the Eocene time $[24,25]$, but since the middle Miocene to the late
Pliocene the northern, especially northeastern plateau still uplifted to a certain extent $[3,18,73,74]$. Thus no consensus view on the specific process of the TP uplift has been universally accepted by academics. Differences in the views of various scholars and inconsistency in the interpretations of various geological records should not be treated as a contradiction, but rather should be considered to be a process of continuously deepened understanding. It is not difficult to understand the existence of regional differences in the plateau uplift. Many recent studies with numerical simulations were exactly aimed at revealing the climatic and environmental effects of different sub-regional uplift of the TP [11,12,75-77]. With the topography of southern or northern $\mathrm{TP}$, western or eastern Asia, and even Africa being taken into consideration, these studies examined the role of sub-regional uplift in the formation and evolution of the Asian monsoon climate. Table 1 briefly summarizes the designs of numerical experiments with topographic variations and main conclusions reached in these studies.

\subsection{Effects of Himalayan-Tibetan Plateau sub-regional uplift on South Asian monsoon and East Asian monsoon evolutions}

Recently some new progress has been made on numerical simulation studies exploring the effects of the TP uplift in different sub-regions on the Asian monsoon climate. Boos and Kuang [11], by removing the main body of the TP and retaining only the narrow terrain of the Himalayas in their numerical experiments, found that the simulated South Asian summer monsoon, precipitation and large-scale atmospheric circulation structures were similar to the simulated results with all topography retained. Thus they concluded that the dynamic barrier effect caused by the uplift of the Himalayas was much more important than the thermal effect of the TP for the formation and development of the South Asian summer monsoon. The presence of only the Himalayas was sufficient to block warm-humid air from the tropical ocean and cold-dry air from the north, so warmhumid air was accumulated above the Indian subcontinent, forming strong South Asian monsoon. This study highlighted the important effect of the Himalayas as a "thermal insulator" in the formation of the South Asian monsoon and thus challenged [69] the widely accepted view that the TP influenced the Asian summer monsoon through its thermal effects [83]. This new view, however, could not explain the formation and evolution of the East Asian monsoon, because the latter had no mountain barrier. This has led some scholars to speculate that to what extent the East Asian Monsoon should be regarded as monsoon [69]. Subsequently, the work by Boos and Kuang [11] was challenged. $\mathrm{Wu}$ et al. [77] pointed out that though their numerical experiments removed the main body of the TP and retained only the Himalayas and adjacent narrow terrain, the surface sensible heat flux of the Himalayas was retained as well, 
Table 1 A summary of major numerical experiments on the influence of the sub-regional scale topographic uplift on the Asian climate and environment in different studies

\begin{tabular}{|c|c|c|c|}
\hline Purpose of experiments & Topographic configurations & Main conclusions & References \\
\hline \multirow{5}{*}{$\begin{array}{l}\text { To examine the effect of the } \\
\text { uplift of southern TP }\end{array}$} & $\begin{array}{l}\text { The main body of the TP was removed and } \\
\text { only the Himalayas and adjacent narrow ter- } \\
\text { rain were retained. }\end{array}$ & $\begin{array}{l}\text { The formation of the South Asian summer monsoon } \\
\text { was controlled by the mechanical effect of the } \\
\text { Himalayas. }\end{array}$ & [11] \\
\hline & $\begin{array}{l}\text { Only the Himalayas and the westward extend- } \\
\text { ed narrow terrain were retained and surface } \\
\text { sensible heat flux was suppressed. }\end{array}$ & $\begin{array}{l}\text { The thermal effect of the plateau had an significant } \\
\text { influence on the formation of the South Asian } \\
\text { summer monsoon. }\end{array}$ & [77] \\
\hline & $\begin{array}{l}\text { Only the uplift of central and southern TP (in- } \\
\text { cluding the Himalayas) to south of } 35^{\circ} \mathrm{N} \text { was } \\
\text { considered. }\end{array}$ & $\begin{array}{l}\text { The uplift of central and southern TP remarkably } \\
\text { intensified the South Asian summer monsoon cir- } \\
\text { culation. }\end{array}$ & [78] \\
\hline & $\begin{array}{l}\text { Only the topography of southern TP including } \\
\text { the Himalayas was retained. }\end{array}$ & $\begin{array}{l}\text { South Asian summer monsoon was mainly affected } \\
\text { by mechanical insulation of the Himalayas. }\end{array}$ & [79] \\
\hline & $\begin{array}{l}\text { Only the Himalayas and adjacent narrow ter- } \\
\text { rain were retained, and the surface sensible } \\
\text { heat flux from the Himalayas or from the } \\
\text { plain of south of the plateau was suppressed. }\end{array}$ & $\begin{array}{l}\text { The intensification of the Indian summer monsoon } \\
\text { was more sensitive to the surface heating from the } \\
\text { India plain than that from the Himalayas. }\end{array}$ & [80] \\
\hline \multirow{3}{*}{$\begin{array}{l}\text { To examine the effect of the } \\
\text { uplift of northern TP }\end{array}$} & $\begin{array}{l}\text { Only the topographic height of the northern } \\
\text { region of the TP was reduced by an average } \\
\text { of about } 800 \mathrm{~m} \text {. }\end{array}$ & $\begin{array}{l}\text { Northern East Asian summer monsoon was intensi- } \\
\text { fied and monsoon precipitation increased with the } \\
\text { uplift of northern TP. }\end{array}$ & [76] \\
\hline & $\begin{array}{l}\text { Only the topographic height of the northern TP } \\
\text { was reduced by an average of about } 600 \mathrm{~m} \text {. }\end{array}$ & $\begin{array}{l}\text { Asian inland arid region expanded and atmospheric } \\
\text { dust concentration increased significantly with the } \\
\text { uplift of northern TP. }\end{array}$ & {$[12]$} \\
\hline & $\begin{array}{l}\text { The topography in central and northern TP was } \\
\text { further considered after keeping the Himala- } \\
\text { yas. }\end{array}$ & $\begin{array}{l}\text { The topography in central and northern TP was re- } \\
\text { sponsible for the development of the East Asian } \\
\text { summer monsoon. }\end{array}$ & [79] \\
\hline $\begin{array}{l}\text { To examine the effect of } \\
\text { western Asian topography }\end{array}$ & $\begin{array}{l}\text { The topography within western Asia }\left(60^{\circ}-\right. \\
\left.80^{\circ} \mathrm{E}, 25^{\circ}-60^{\circ} \mathrm{N}\right) \text { was removed. }\end{array}$ & $\begin{array}{l}\text { The western plateau blocked cold air thus enhanced } \\
\text { the atmospheric instability in the South Asian } \\
\text { monsoon region. }\end{array}$ & [81] \\
\hline $\begin{array}{l}\text { To examine the effect of } \\
\text { eastern Asian topography }\end{array}$ & $\begin{array}{l}\text { The topography within eastern Asia }\left(80^{\circ}-\right. \\
\left.120^{\circ} \mathrm{E}, 0^{\circ}-60^{\circ} \mathrm{N}\right) \text { was removed. }\end{array}$ & $\begin{array}{l}\text { The eastern plateau intensified the large-scale up- } \\
\text { ward current in the lower troposphere. }\end{array}$ & [81] \\
\hline \multirow{2}{*}{$\begin{array}{l}\text { To examine the effect of the } \\
\text { Iranian Plateau }\end{array}$} & $\begin{array}{l}\text { Under the condition without the TP, only the } \\
\text { mechanical forcing or thermal effect of the } \\
\text { Iranian Plateau was included. }\end{array}$ & $\begin{array}{l}\text { South Asian monsoon circulation north of } 20^{\circ} \mathrm{N} \text { was } \\
\text { mainly controlled by the thermal forcing of the } \\
\text { Iranian Plateau. }\end{array}$ & [77] \\
\hline & $\begin{array}{l}\text { The Iranian Plateau included with the presence } \\
\text { of whole TP. }\end{array}$ & $\begin{array}{l}\text { The existence of the Iranian Plateau intensified the } \\
\text { South Asian summer monsoon and restrained the } \\
\text { East Asian summer monsoon. }\end{array}$ & [79] \\
\hline $\begin{array}{l}\text { To examine the effect of the } \\
\text { Mongolian Plateau }\end{array}$ & $\begin{array}{l}\text { The topography of the Mongolian Plateau } \\
\text { (between } 42^{\circ}-55^{\circ} \mathrm{N} \text { ) on the Asian continent } \\
\text { was removed. }\end{array}$ & $\begin{array}{l}\text { Central Asian precipitation relatively increased } \\
\text { while the precipitation in the northern East Asian } \\
\text { monsoon region decreased. }\end{array}$ & [78] \\
\hline \multirow{4}{*}{$\begin{array}{l}\text { To examine the effect of the } \\
\text { African topography }\end{array}$} & $\begin{array}{l}\text { The topography of the entire African continent } \\
\text { was removed. }\end{array}$ & $\begin{array}{l}\text { The presence of the African topography decreased } \\
\text { the Indian Peninsula monsoon precipitation. }\end{array}$ & [75] \\
\hline & $\begin{array}{l}\text { The topography of the African continent was } \\
\text { removed or retained as the only topography. }\end{array}$ & $\begin{array}{l}\text { The African topography advanced the onset of the } \\
\text { Indian monsoon and intensified the monsoon in } \\
\text { early summer season. }\end{array}$ & [81] \\
\hline & $\begin{array}{l}\text { The topographic height of the eastern-southern } \\
\text { African plateau }\left(10^{\circ}-40^{\circ} \mathrm{E}, 30^{\circ} \mathrm{S}-20^{\circ} \mathrm{N}\right) \text { was } \\
\text { reduced by an average of about } 400 \mathrm{~m} \text {. }\end{array}$ & $\begin{array}{l}\text { The uplift of the eastern-southern African plateau } \\
\text { led to the intensification of the South Asian sum- } \\
\text { mer monsoon and the increase in the monsoon pre- } \\
\text { cipitation. }\end{array}$ & [76] \\
\hline & $\begin{array}{l}\text { The African continent and topography to south } \\
\text { of the equator was removed and replaced by } \\
\text { ocean. }\end{array}$ & $\begin{array}{l}\text { The southern African plateau helped to enhance the } \\
\text { Mascarene High and the low-level westerly in the } \\
\text { Indian Peninsula. }\end{array}$ & [82] \\
\hline
\end{tabular}

and therefore their experimental results actually included the thermal impact of the southern TP, not only the dynamic effect of the Himalayas. The numerical experiments by $\mathrm{Wu}$ et al. [77] further illustrated that monsoons in different regions were controlled respectively by the land-sea distribution and the thermal forcing of plateaus in different regions, whereas the East Asian monsoon and the eastern part of the South Asian monsoon were influenced by the thermal forcing of the TP. More recently, Boos and Kuang published another paper [80] to further explore the effect of the surface sensible heat flux of the Himalayas. In numerical ex- periments with the main body of the TP removed and only the narrow-long Himalayan topography retained, by suppressing the surface sensible heat flux in the topographic area or the northern Indian plain area south of the Himalayas, they found that compared with the high-elevation region in the Himalayas, the surface sensible heat flux of the plain area south of the Himalayas was more important to the intensification of the South Asian summer monsoon, thus partially amended their previous view [11]. They thought that surface sensible heat flux exercised the influence upon the development of the South Asian monsoon to a certain 
extent, but the contribution from the thermal effect of the plateau was limited. It is thus clear that although Boos and Kuang $[11,80]$ and $\mathrm{Wu}$ et al. [77] came to a common conclusion of the decisive effect of the Himalayas and the neighboring mountains on the establishment of the South Asian monsoon, the simulation study by Boo and Kuang $[11,80]$ indicated that the dynamic barrier exerted a dominant effect on the intensification of the South Asian monsoon. On the contrary, the results from $\mathrm{Wu}$ et al. [77] showed that the contribution from the topographic thermal effect of the southern plateau was greater. Therefore, the relative importance of the dynamic and thermal effects of the large topography in southern TP on the South Asian monsoon needs to be further studied.

In the consideration of regional differences in uplift times of the Himalayan-Tibetan Plateau region, Zhang et al. [78] recently performed a uplift experiment containing only the central and southern TP south of about $35^{\circ} \mathrm{N}$ (with the Himalayas included), and the results also indicated that the uplift of central and southern TP mainly enhanced the South Asian summer monsoon circulation and westerlies over the northern Arabian Sea significantly, and increased the South Asian monsoon precipitation remarkably. A further experiment including the uplift of the northern TP mainly increased precipitation in the northern East Asian monsoon region $\left(34^{\circ}-42^{\circ} \mathrm{N}, 105^{\circ}-120^{\circ} \mathrm{E}\right)$, and enhanced the East Asian summer monsoon circulation significantly. Based on the geological evidence of the tectonic uplift of the northern TP since the Pliocene, Zhang and Liu [76] designed numerical experiments with topographic height reduced in a limited range (average topography decreased by about $800 \mathrm{~m}$ ) also found that the uplift of northern TP led to intensified northern East Asian summer monsoon, thus increased precipitation in the northern East Asian monsoon region north of the Yangtze River. Most recently, Tang et al. [79] conducted a series of sensitivity experiments on the uplift effect of different sub-regions of the TP on the South Asian and East Asian summer monsoons by using a regional climate model with a higher resolution. Their results also indicated some differences in responses of the Indian summer monsoon and East Asian summer monsoon to the TP uplift: the former was mainly controlled by the mechanical barrier effect of the topography in the southern plateau, while the latter was strengthened due to the thermal forcing in the central and northern plateau. In particular, the increase of precipitation in northern China was mainly influenced by the uplift of central TP. Not only did the uplifts of southern and northern TP have different climatic and environmental influences, but the effects of the eastern and western topography as well. The numerical experiments of Chakraborty et al. [81] discovered that the Asian topography to the west of $80^{\circ} \mathrm{E}$ had a greater impact than that to the east of $80^{\circ} \mathrm{E}$ on the onset of the Indian summer monsoon and associated precipitation. The western plateau had a barrier effect on the cold air from high latitudes, favored the atmosphere over south Asia to reach unstable conditions earlier; while the eastern plateau played a minor role in promoting the development of deep convection over the entire Indian region, despite enhancing large-scale ascending air flow in the lower troposphere. It is thus clear that the different forms of tectonic uplifts could lead to regional differences in the evolution of the Asian monsoon. The uplifts in different sub-regions had different impacts upon the formation and development of the Asian monsoon subsystems including the South Asian monsoon and East Asian monsoon.

\subsection{Influences of the uplift of northern Tibetan Plateau upon the aridification of inland Asia and dust cycles}

The TP and its subregional uplifts exerted a considerable influence on not only the evolution of the Asian monsoon and other subsystems, but also the aridification and dust cycle in inland Asia. A large amount of geological evidence indicated that the Asian inland aridity had been in place for a long time. In the early Tertiary the climate in China was mainly controlled by the planetary wind system, with a wide arid zone stretching from west to east across the Chinese mainland. The northern part of eastern China had not yet been controlled by the monsoon until the Neogene, and from then on the arid zone was only limited in northwest China [35-37]. Studies on the eolian deposition rate and deposition fluxes in the North Pacific [84], Loess Plateau [4] and Xinjiang [34] all showed that the aridification of inland Asia was markedly intensified in the late Oligocene-early Miocene period, and several strong drought events also occurred during the long-term evolution. With a close connection to the arid environment, the Asian ancient dust was considered as an important feedback factor in global climate change [85], and thus received extensive attention in paleoclimatic and paleoenvironmental studies. However, detailed records of arid environment were limited before the Miocene, and its corresponding relationship with the TP uplift remained unclear. An et al. [42] pointed out that the four periods during which the Asian dust flux significantly increased (24-22 Ma, 16-14 Ma, 10-7 Ma and 4.5-2.6 Ma) since the Miocene were generally in accordance with the occurrence of tectonic uplift of the TP. In particular, the intensified aridification of inland Asia in the middle Miocene and Pliocene was considered related to the apparent tectonic activities in the northern and northeastern TP. Some scholars argued that in some northern regions of the TP such as northern Tibet, Gansu and Qinghai, marked uplifts might still occur since $15 \mathrm{Ma}$, with continuous growing outwards on both sides of the northeastern and eastern plateau. The terrain of Tianshan and Mongolia also uplifted considerably during this period [5,69], and even in the late Pliocene tectonic uplift still occurred in the northern TP $[6,73]$. Some scholars believed that the uplift of northern TP could produce the denudation at the northern edge of the plateau, and thus provide dust material for the Asian dust 
source region, contributing to promoting Asian dust cycle and increasing the downstream dust flux $[5,86]$. Existing eolian records from oceans and continents showed that since the middle Pliocene the aridification of inland Asia was intensified and the ancient dust flux followed a significantly increasing trend at the tectonic time scale.

By using a global climate model with a dust module, Shi et al. [12] recently conducted a series of sensitivity simulations on Asian dust cycles, based on reconstructed dust source scenarios during the middle Pliocene, last glacial maximum and present day, to evaluate relative contributions of northern TP uplift and global climate change to the increased dust sedimentation fluxes. In the experiment of the mid-Pliocene, the topography of northern TP was reduced within a limited range, i.e., the height of northern TP in the Pliocene reduced by about $600 \mathrm{~m}$ from its current height, with a maximum reduction of $1400 \mathrm{~m}$. The simulated results indicated that the area of the Asian inland arid region or the dust source region was remarkably enlarged and the atmospheric dust concentration increased significantly (Figure 1) in response to only the small-scale uplift of northern TP from the middle Pliocene to present day. Numerical simulations could better reproduce the activities of atmospheric dust cycle during special geological periods, and the results from simulations were consistent with the geological evidence that the dust deposition fluxes had significantly increased in the Loess Plateau and the North Pacific region since the middle Pliocene. This study suggested that since the middle Pliocene, even the occurrence of a limited uplift in northern TP could exert noticeable influences on the aridity and dust cycle in inland Asia. Further analysis also showed that the significant increase of Asian dust mass concentration, which was closely connected to arid environment, could be attributed to the combined effect of the tectonic uplift of northern TP and the influence of global climate cooling on the dust source region and atmospheric circulation; but in different deposition regions, relative contributions from the two factors differed.

\subsection{Contributions of other tectonic movements to the establishment and development of the Asian monsoon}

In addition to the effect of the TP, some numerical experiment studies indicated that topography in other regions also contributed to the formation of the Asian monsoon to some extent. For example, based on an experiment with the TP uplift (Mongolian Plateau excluded) and a further experiment by including the uplift of Mongolian Plateau, Zhang et al. [78] showed increased precipitation in the Central Asian inland $\left(42^{\circ}-50^{\circ} \mathrm{N}, 80^{\circ}-110^{\circ} \mathrm{E}\right)$ and reduced precipitation in northern East Asian, which was different from the effects of the TP uplift. Therefore, if the uplift of Mongolian Plateau [87] occurred later than the uplift of the TP, it could be speculated that the several tectonic uplifts in Asia might not always lead to intensified arid in Central Asia. Wu et al. [77], through numerical experiments by only considering the dynamic and thermal effects of the Iranian Plateau (the TP excluded), found that the monsoon circulation in the
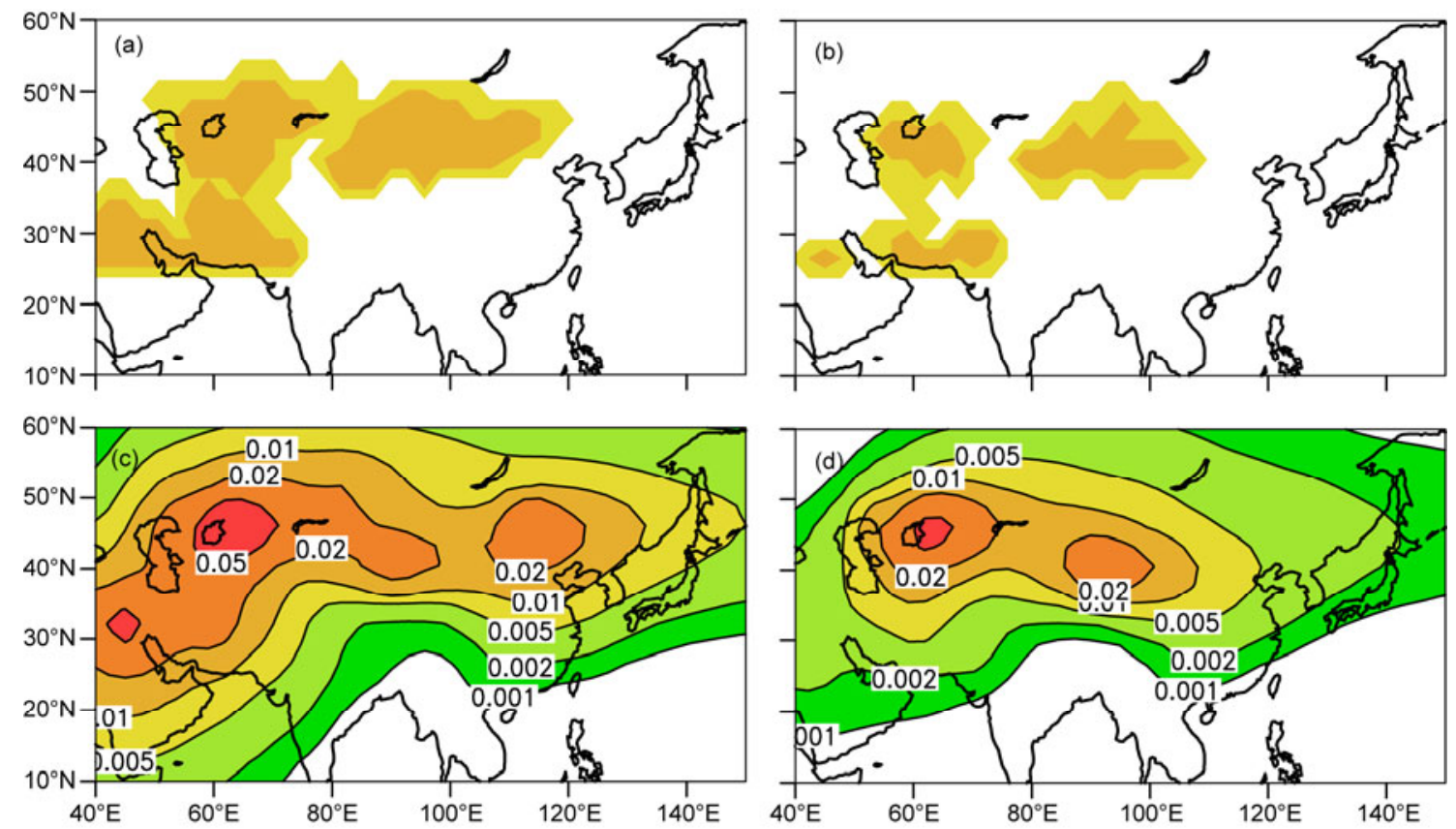

Figure 1 Simulated distributions of the Asian dust source areas north of $25^{\circ} \mathrm{N}$ and atmospheric column dust loading. (a) dust source areas at present-day, (b) same as (a) but for the Pliocene with lower topography in northern TP, (c) dust loading at present-day (kg/m²), and (d) same as (c) but for the Pliocene with lower topography in northern TP. The shadow areas of dark yellow and light yellow indicate arid and semi-arid areas, respectively, in (a) and (b). Redrawn on the basis of the modeling data from [12]. 
South Asian region south of $20^{\circ} \mathrm{N}$ was mainly regulated by the land-sea thermal contrast, while to the north it was controlled by the thermal forcing of the Iranian Plateau, showing considerable effects of the Iranian Plateau in maintaining the South Asian monsoon. The sub-regional climatic simulation by Tang et al. [79] also indicated that the Iranian Plateau would promote the development of the South Asian summer monsoon and constrain the East Asian summer monsoon.

In fact, effects of tectonic movements that caused the change in the Asia monsoon were not limited to Asian region itself. Some studies pointed out that the presence of the African plateau was relevant to the Asian monsoon. In numerical experiments by Chakraborty et al. [81] the removal of the African topography could delay the onset of the South Asian summer monsoon and weaken its intensity, while once the South Asian summer monsoon was established, the influence of topography on the precipitation intensity was limited. Earlier experiments by Chakraborty et al. [75] demonstrated the importance of the African topography in the formation of the Indian monsoon, but the result was that the removal of the African topography led to increased precipitation in the Indian Subcontinent. Based on the geological evidence of significant tectonic uplifts in eastern and southern regions of Africa since the Pliocene, the simulation research by Zhang and Liu [76] showed that the uplift in east-south Africa could cause enhanced South Asian summer monsoon and corresponding increase in precipitation, while it had limited impacts on the East Asian summer monsoon, which was in contrast to the effect of the uplift of northern TP. By removing the African continent as well as plateaus south of the equator, Jin et al. [82] found that the removal of southern African continent resulted in weakened Mascarene anticyclone and southerly winds north of the anticyclone. Meanwhile, the low-level westerly winds in the Arabian Sea and Indian Subcontinent were reduced significantly. This indicated that the presence of the southern African plateau and land contributed to the intensification of the South Asian summer monsoon.

\section{Discussions about a number of scientific issues in the plateau uplift-climate change research}

\subsection{Comparison of the influence of the Tibetan Plateau uplift with other factors on the formation and change of the Asian monsoon-arid environment}

The TP uplift, as a major geological event during the Cenozoic era, has exerted a profound impact upon the Asian and global climate and environment despite the fact that the history and model of its uplift have yet been entirely clear. From various numerical experiments with changed topography, the TP uplift has caused the formation and development of the Asian monsoon as well as intensified inland aridification by the dynamic and thermal effects of the TP.
A growing number of studies have also revealed that regional differences in the Asian monsoon evolution may be caused by different forms of tectonic uplift of the TP. Besides the effect of tectonic uplift, the evolution of the Asian monsoon may also be subject to the influence of other forcing factors. For example, Prell and Kutzbach [88] performed a series of sensitivity experiments, comparatively analyzed contributions of different factors such as the plateau uplift, glacial-interglacial ice volume, Earth's orbital parameters and change in the concentrations of atmospheric greenhouse gases to the South Asian monsoon, and their results showed that the TP uplift had the greatest impact and it was the most important external forcing factor in the evolution of South Asian monsoon.

The monsoon was generally considered as the response of the atmosphere to seasonal changes in the land-sea thermal contrast due to the annual cycle of solar radiation. Some numerical experiments indicated that changes in the distribution of land and sea had strong influence on the Asian monsoon. For example, the expansion of the Eurasian continent due to the retreat of the Paratethys Sea could also lead to an increase in the Asian monsoon precipitation and intensified inland aridification [59,60]. The experiment without the Australian continent showed that the Australian anticyclone and the southeast monsoon in its northern side was weakened significantly, and the Mascarene anticyclone and the southeast monsoon to its north was affected and weakened as well [82]. The experiment and analysis by Qian and Qian [89] showed that the land-sea distribution was a fundamental factor compared with the TP uplift in the formation of the present day atmospheric circulation and monsoon although the heating of the TP, especially latent heating was strengthened as the plateau topography was elevated. Some numerical experiments showed the existence of a weak monsoon even under the condition of an idealized land-sea distribution without any topography [90,91]. However, the latitude of the land location was a key factor in the formation of monsoon, and the tropical land was more important in maintaining the South Asian monsoon and associated precipitation, given the fact that the TP uplift would significantly enhance the Asian monsoon. Without the TP, the Asian monsoon only appeared at low latitudes, which was in accordance with the results of geological reconstruction of the Paleogene environment pattern [37]. In the experiment of phased uplift, the rain belt of the East Asian summer monsoon did not reach the north to the Yangtze River until the TP height exceeded half of its current value, and then the northerly winter monsoon began to prevail in winter in the northern region of East Asia [10]. $\mathrm{Wu}$ et al. [92] performed a set of interesting numerical experiments. They showed that the East Asian summer monsoon was significantly weakened when the plateau center was moved from $87.5^{\circ} \mathrm{E}, 32.5^{\circ} \mathrm{N}$ westward to $60.0^{\circ} \mathrm{E}, 32.5^{\circ} \mathrm{N}$. They argued that the forced circulations at the plateau scale and continental scale mutually reinforced and finally allowed 
the East Asian monsoon to expand northward to North China when the center of the plateau located exactly at the Asian low latitudes near $87.5^{\circ} \mathrm{E}$. Although it was claimed that the global monsoon was not maintained by the land-sea thermal contrast but driven by the east-west thermal difference at the planetary scale [93], or monsoon was the result of the seasonal displacement of the Intertropical Convergence Zone (ITCZ), thus monsoon would appear even without land [94], this kind of "monsoon" should be a phenomenon within a limited tropical region. Therefore, although the establishment of the South Asian monsoon was mainly related to the Himalayas, we believe that the uplift of the main body of the TP, especially the northern plateau $[10,76]$ played an important role in the formation of the East Asian monsoon, particularly its northward development.

Some numerical experiments $[9,54-56]$ stated that the TP uplift contributed significantly to the formation of arid climate in the mid-latitudes, but the TP uplift was not the only factor for the inland aridification in Asia. Aridification could also be affected by the land-sea distribution (e.g. [59]), global climate change (e.g. [95]), etc. Though the TP uplift caused the aridification in the Central Asia, China inland and North Africa, it might not be the fundamental reasons for the formation of these arid regions [96]. The distribution of the annual average precipitation in response to the phased uplift of the TP showed that North Africa and Eurasian inland at about $25-45^{\circ} \mathrm{N}$ were still arid regions even in the absence of the TP, but the plateau uplift undoubtedly further enhanced aridification in the inland arid regions. Without topography, rainy areas located to the south of about $22^{\circ} \mathrm{N}$ from India to East Asia, thus this tropical monsoon precipitation was essentially determined by the land-sea distribution rather than the presence of the TP. This understanding was consistent with the fact of the paleo-environmental evolution in Asia revealed by a large number of geological records since the Cenozoic. Integrated analysis of Chinese paleoplant and deposition data [8] indicated that the arid climate in Northwest China had been in place since early Tertiary. The aridification in Central Asian inland was further exacerbated [97] since the late Cenozoic, which might be the result of the TP uplift.

\subsection{Origin of the South Asian and East Asian monsoons}

The aforementioned results from numerical simulations showed that the maintenance of different subsystems of the Asian monsoon was influenced by the uplifts in different regions of the TP. If different topographic units did form in different eras, then in theory the South Asian and East Asian monsoons as well as the monsoon phenomena in different regions of southern and northern East Asia may develop asynchronously. The existence of the Himalayas $[11,77]$ or the distribution of land and sea alone [90,91] was sufficient to stimulate the South Asian monsoon with a tropical nature, and the land-sea distribution determined the formation of the monsoon in the low-latitude regions of East Asia [10]. However, the formation of the monsoon in northern East Asia could not be separated from the uplift of the main body of the TP, especially the effect of the uplift of northern plateau. Experiments on phased uplift of the TP [10] indicated that both the summer southerly wind and rain belt in eastern China gradually expanded northward with the TP uplift, while the winter meridional wind in the lower troposphere in the northern region of East Asia gradually transferred from southerly wind into northerly wind with the plateau uplift. When the TP topography uplifted to half of its present-day height, the surface southerly wind could extend northward to near $30^{\circ} \mathrm{N}$ in summer, and the northerly wind started to prevail in North China in winter. Only when the TP reached its present height the southerly wind to the east of the plateau in summer advanced northward to the north of $40^{\circ} \mathrm{N}$.

Chinese scholars started to use geological records to explore formation times of the Asian monsoon climate in the 1980s [98]. However, at present there are a number of difficulties to conduct an overall comparison between the results of numerical simulations on the climatic effects of the regional uplift and geological records to explore the origin of the Asian monsoon climate. With regard to the regional uplift, the exact period, magnitude and scale of the uplift at different regions of the TP from geological evidence remain to be unified although the results from numerical simulations have provided the possible climatic and environmental effects of the uplifts in different regions of the plateau. The reliability of the simulated response to the regional uplift also needs to be further improved, especially to consider how to reduce the dependence of the simulated results on the model and to lower the uncertainty on subcontinent scales. With regard to environmental change, eolian sediments in northern China [4,33,37], river and lake sediments [99], and reconstructions of environmental patterns from the geological-biological evidence $[8,36,37]$ suggested that the formation of the East Asian monsoon was around 22-25 Ma. However, most of geological evidences about the South Asian monsoon were too short and the longest record was only about $12 \mathrm{Ma}$ [29]. Results of above-mentioned reconstructions of environmental patterns [36] showed that southwestern China had already transformed from an arid climate into a humid climate in the early Miocene, indicating the important influence of the South Asian monsoon on southwestern China at that time.

A lot of noteworthy scientific questions can be proposed through comparison between modeling results and geological evidence relevant to the TP uplift, monsoon and aridity. On the one hand, if the uplift of the Himalayas was earlier than that of northern TP, then the formation of the South Asian monsoon should be earlier. So it is reasonable to doubt whether records on early South Asian monsoon were somehow missing. On the other hand, since numerical sim- 
ulations supported the important effect of the uplift of northern TP on the East Asian monsoon, could the significant intensification of the East Asian monsoon around 22$25 \mathrm{Ma}$ be attributed to the early uplift of northern TP? We believe that it is still too early to give exact answers to these questions, but the existence of these problems also triggers further research in this field.

\subsection{Feedback effects and the nonlinear response of climatic and environmental changes in the process of plateau uplift}

In the past the research on climatic and environmental effects of the TP uplift was more focused on the dynamic and thermal impacts. In fact, a series of climatic feedback mechanisms existed in the process of the TP uplift, which could further enhance the direct effect of the uplift. These feedback mechanisms at least included: (1) changes in vegetation: Regional vegetation was very sensitive to the climate response to the plateau uplift [100], and the change in vegetation would usually further enlarge the climate change caused by the plateau uplift and other factors [61]; (2) accumulation of ice and snow: Ice and snow on the TP would increase with the uplift of the plateau. The increase in surface albedo due to the increased ice and snow would weaken the surface heating effect during the process of the plateau uplift [101], thus leading to intensified winter monsoon and weakened summer monsoon, which was opposite to the direct thermal effect on summer monsoon due to the TP uplift; (3) inland aridification and intensified Asian dust cycle: The TP uplift exacerbated the aridification in western and northern sides of the plateau, thereby increasing emissions of Asian dust [12]. Atmospheric dust cycle further influenced the climate by changing the atmospheric radiation balance, microphysical properties of clouds, atmospheric chemical process and bio-geochemical cycles [85], and the increase in atmospheric dust may suppress precipitation, further intensifying aridification [102]; and (4), atmospheric $\mathrm{CO}_{2}$ concentration decreased: The TP uplift could exacerbate weathering and erosion [57], and increase the rate of production of plankton by transporting Asian dust with iron into ocean through atmospheric circulation [103], resulting in lower $\mathrm{CO}_{2}$ concentration in the atmosphere, eventually leading to global temperature change. It is because of the existence of a large number of positive and negative feedback processes that the relationship between the plateau uplift and climate change becomes more complex.

The complexity of the environmental effects of the TP uplift is also reflected in the fact that climatic and environmental changes in response to the plateau uplift are not a simple linear process. In the case of a linear response to forcing, when the plateau uplifted slowly and gradually it would lead to gradual and slow climatic changes; when the plateau uplifted in a phased or jumping pace, it would cause an abrupt climate change. However, the actual situation is not so simple. Due to the non-linear characteristics of the climatic system and various feedback mechanisms, the linear uplift of topography may cause a nonlinear climatic response. For example, in the series of experiments where topographic height increased linearly [10], the soil moisture and monsoon indices over different regions showed significant nonlinear changes. With the TP uplift, the surface heating source was usually enhanced and this enhanced heating source promoted the development of the East Asian summer monsoon. However, when the plateau uplift entered into the cryosphere, the accumulated ice and snow, damping the surface heating, may lead to asynchronously responses of the Asian summer monsoon with the plateau uplift. More importantly, in the climatic system with nonlinear characteristics, there may be one (or several) critical height during the course of the uplift [104]. When the plateau uplifted to a point near the critical height, even a slight change in the height could cause substantial climatic responses, and in this case the abrupt climatic change was independent of the speed of uplift. When the plateau uplifted through the critical height, the gradual uplift may even lead to an abrupt climate change, probably causing a series of enormous changes in the atmospheric circulation, atmospheric thermal structure, Asian monsoon and global climate. For example, before the TP uplift reached half of its modern height, the monsoon phenomena characterized by the reversal of nearsurface winds between winter and summer in the areas north of $30^{\circ} \mathrm{N}$ in East Asia did not exist [10]. Therefore when the TP height exceeded half of its modern value, the northern East Asian monsoon may experience a transition from quantitative change to qualitative change. The impact of the plateau uplift was not limited to the period of uplift. Once the uplift of the plateau exceeded a certain stage, its impact would be irreversible. A typical example is that the TP uplift on the tectonic scale not only affected climatic evolution on the tectonic scale, but also amplified the variability of the Asian monsoon on the orbital scale after the TP uplift $[105,106]$.

In summary, to further strengthen the research on various feedback mechanisms and nonlinear responses of climatic and environmental changes is a key for the in-depth understanding of the influence of the TP uplift upon the Asian monsoon-arid environment. Not only do we need to identify the spatial and temporal scales, and additive effects of each feedback during the process of the uplift, but also need to clarify the relationships among tectonic uplift events, major environmental changes and critical heights in the plateau uplift. This requires further research to be done.

\subsection{Uncertainty of geological records and numerical simulations in the study of climatic and environmental effects of the plateau uplift}

Both geological records and numerical simulations are important for the study on the impact of the TP uplift on the 
Asian monsoon-arid environment. However, at present both have their shortcomings. In addition to the non-uniform spatial distribution and the limitation in time span, deficiencies of geological records are mainly reflected in the fact that various evidences of uplifts and dating from different sources have yet to be unified, with different views on the interpretation for some environmental records. For example, the significant increased sedimentation rate at about 3.6 Ma could be related to the uplift of northern TP and global climate change [107]. Since paleoenvironmental records may contain the information of responses to both regional tectonic events and global change, it is difficult to exactly identify the cause-effect relationship between the plateau uplift and climate change. Furthermore, the feedback effects and non-linear responses of the earth system to the plateau uplift make the relationship between the tectonic events and climate changes reflected by geological records even more complicated.

Although the simulated climatic effects of the plateau uplift in various climatic models are consistent to a certain extent among them, obvious differences still exist in some aspects. For example, there are different views on the relative importance of the dynamic and thermal effects of southern TP on the South Asian monsoon, and further research is needed to assess their relative roles quantitatively. Currently the resolution of numerical models used to study the effect of the plateau uplift is to be further improved. Compared with the global GCMs, regional climate models have higher spatial resolution and better descriptions of the dynamical and physical processes on small and medium scales, thus are able to simulate the effects of regional and local topography on the monsoon and arid climates more accurately. However, the regional model also has its own limitations. It does not allow the feedback of atmospheric circulation within the model domain onto the global circulation outside. Current climate models are not perfect in describing various feedback mechanisms in the climate system and parameterizations of the processes of physical-chemicalgeobiological cycles, and in handling of the atmosphereocean-land-ice coupling, so the results of simulation may show a certain climate drift and model-dependence. These deficiencies in turn influence the sensitivity of model climate response to topographic changes. These issues need to be concerned in future researches in order to further reduce the uncertainty in the study on the climatic and environmental effects of the TP uplift.

\section{Concluding remarks}

This paper reviews the research on the influence of the TP uplift upon the Asian monsoon-arid environmental evolution from a perspective of climatic numerical simulations combined with key geological records. It systematically summarizes the results of three types of numerical simula- tion experiments, including the uplift of the plateau as a whole, phased uplift and sub-regional uplift. With the development of climate models, from relatively simple atmospheric general circulation models, to coupled oceanatmosphere models, and then the complex climate system models, there is a clear need to use these more advanced climate models for in-depth understanding of the environmental effects of the plateau uplift. One important conclusion demonstrated in this paper is that tectonic uplifts in different forms have significant differences in their climatic and environmental effects. In other words, the influences of the topographic uplifts in different regions of the TP upon sub-systems of the Asian monsoon are different. Results from a large number of numerical simulations have indicated that the land-sea distribution and the uplift of the Himalayas play a decisive role in the establishment and development of the South Asian monsoon. In contrast, the formation and evolution of the East Asian monsoon, the enhancement of inland aridification north of the TP and the intensification of the Asian dust cycle are mainly attributed to the uplift of the main body of the TP, especially the northern plateau.

Breakthroughs in further research on the influence of the TP uplift upon the Asian monsoon-arid environmental evolution will largely depend on a good integration between geological records and numerical simulation studies. In recent years, some scholars began to quantitatively reconstruct regional paleo-elevation using geological records (e.g. [108]). With the continuous accumulation of data, direct comparison between geological evidences with more accurate dating and numerical simulations may become possible. To achieve this, the work on reconstruction of the threedimensional paleo-elevation during geological periods and its changes over time needs to be further strengthened. The climatic and environmental records during geological periods are actually the comprehensive results under influences of various impact factors, which also raise new requirements for climate numerical simulations. It is necessary to differentiate the relative contributions of sub-regional tectonic uplifts during different periods from those of global climate change to the Asian monsoon-arid environment by using numerical models with higher resolution and with more detailed description of physical processes. Another important issue is to assess the impacts of regional tectonic uplifts during different periods on the seasonal march of the atmospheric circulation [14,109]. In conclusion, in order to correctly assess the climatic and environmental effects of the TP uplift, geological records and numerical simulation studies must be integrated more closely. Through the analysis of geological records, further research questions can be proposed for paleoclimate modeling and the model results can be validated by comparison with geological records. In this way numerical simulations and geological evidences can help to understand the phenomena observed in geological records as well as their mechanisms. 
The first author thanks Drs. Zhiguo Shi and Ran Zhang for their help in writing this paper. This work was supported by the Strategic Priority Research Program of the Chinese Academy of Sciences (XDB03020601), the National Basic Research Program of China (2010CB833406) and the National Natural Science Foundation of China (41290255 and 41075067).

1 Yin A. Harrison T N. Geologic evolution of the Himalayan-Tibetan orogen. Ann Rev Earth Planet Sci, 2000, 28: 211-280

2 Molnar P, England P, Martinod J. Mantle dynamics, uplift of the Tibetan Plateau, and the Indian Monsoon. Rev Geophys, 1993, 31: 357-396

3 An Z S, Kutzbach J E, Prell W L, et al. Evolution of Asian monsoons and phased uplift of the Himalaya-Tibetan Plateau since Late Miocene times. Nature, 2001, 411: 62-66

4 Guo Z T, Ruddiman W F, Hao Q Z, et al. Onset of Asian desertification by 22 Myr ago inferred from loess deposits in China. Nature, 2002, 416: 159-163

5 Li G J, Pettke T, Chen J. Increasing Nd isotopic ratio of Asian dust indicates progressive uplift of the north Tibetan Plateau since the middle Miocene. Geology, 2011, 39: 199-202

6 Li J J, Fang X M. Uplift of the Tibetan Plateau and environmental changes. Chin Sci Bull, 1999, 44: 2117-2124

7 Molnar P. Mio-Pliocene growth of the Tibetan Plateau and evolution of East Asian climate. Palaeontol Electron, 2005, 8: 1-23

8 Sun X J, Wang P X. How old is the Asian monsoon system?-Palaeobotanical records from China. Palaeogeogr Palaeoclimatol Palaeoecol, 2005, 222: 181-222

9 Kutzbach J E, Prell W L, Ruddiman W F. Sensitivity of Eurasian climate to surface uplift of the Tibetan Plateau. J Geol, 1993, 101: 177-190

10 Liu X D, Yin Z Y. Sensitivity of East Asian monsoon climate to the uplift of the Tibetan Plateau. Palaeogeogr Palaeoclimatol Palaeoecol, 2002, 183: 223-245

11 Boos W R, Kuang Z M. Dominant control of the South Asian monsoon by orographic insulation versus plateau heating. Nature, 2010, 463: 218-222

12 Shi Z G, Liu X D, An Z S, et al. Simulated variations of eolian dust from inner Asian deserts during late Pliocene-Pleistocene periods. Clim Dyn, 2011, 37: 2289-2301

13 Copeland P. The when and where of the growth of the Himalaya and Tibetan Plateau. In: Ruddiman W, ed. Tectonic Uplift and Climate Change. New York: Plenum Publishing Corporation, 1997. 19-40

14 Harris N B W. The elevation history of the Tibetan Plateau and its implications for the Asian monsoon. Palaeogeogr Palaeoclimatol Palaeoecol, 2006, 241: 4-15

15 Wang C S, Dai J G, Liu Z F, et al. The uplift history of the Tibetan Plateau and Himalaya and its study approaches and techniques: A review (in Chinese). Earth Sci Front, 2009, 16: 1-30

16 Shi Y F, Liu D S. A preliminary report of scientific survey in Mount Xixabangma (in Chinese). Chin Sci Bull, 1964, 10: 928-938

17 Hsü J, Tao J R, Sun X J, et al. On the discovery of a Quercus semicarpifolia bed in Mount Shisha Pangma and its significance in botany and geology (in Chinese). Acta Bot Sin, 1973, 15: 103-119

18 Li J J, Wen S X, Zhang Q S, et al. A discussion on the period, amplitude and type of the uplift of the Qinghai-Xizang Plateau (in Chinese). Sci Sin, 1979, 22: 608-616

19 Harrison T M, Copeland P, Kidd W S F, et al. Raising Tibet. Science, 1992, 255: 1663-1670

20 Quade J, Cerling T E, Bowman J R. Development of Asian monsoon revealed by marked ecological shift during the Latest Miocene in northern Pakistan. Nature, 1989: 342: 163-166

21 Kroon D, Steens T N F, Troelstra S R. Onset of monsoonal related upwelling in the western Arabian Sea. Proc ODP, Sci Results, 1991, 17: 257-263

22 Coleman M, Hodges K. Evidence for Tibetan uplift before $14 \mathrm{Myr}$ ago from a new minimum age for east-west extension. Nature, 1995, 374: 49-52

23 Spicer R A, Harris N B W, Widdowson M, et al. Constant elevation of southern Tibet over the past 15 million years. Nature, 2003, 421: $622-624$

24 Wang C S, Zhao X X, Liu Z, et al. Constraints on the early uplift history of the Tibetan Plateau. Proc Natl Acad Sci USA, 2008, 105: 4987-4992

25 Rowley D B, Currie B S. Palaeo-altimetry of the late Eocene to Miocene Lunpola basin, central Tibet. Nature, 2006, 439: 677-681

26 Liu T S, Ding Z L. Chinese loess and the paleomonsoon. Ann Rev Earth Planet Sci, 1998, 26: 111-145

27 An Z S. The history and variability of the East Asian paleomonsoon climate. Quat Sci Rev, 2000, 19: 171-187

28 Wang P X. Global monsoon in a geological perspective. Chin Sci Bull, 2009, 54: 1113-1136

29 Gupta S M. Indian monsoon cycles through the last twelve million years. Earth Sci India, 2010, 3: 248-280

30 Ding Z L, Xiong S F, Sun J M, et al. Pedostratigraphy and paleomagnetism of a similar to $7.0 \mathrm{Ma}$ eolian loess-red clay sequence at Lingtai, Loess Plateau, north-central China and the implications for paleomonsoon evolution. Palaeogeogr Palaeoclimatol Palaeoecol, 1999, 152: 49-66

31 Sun D H, Shaw J, An Z S, et al. Magnetostratigraphy and paleoclimatic interpretation of a continuous 7.2 Ma Late Cenozoic eolian sediments from the Chinese Loess Plateau. Geophys Res Lett, 1998, 25: 85-88

32 Huang Y S, Clemens S C, Liu W G, et al. Large-scale hydrological change drove the late Miocene $\mathrm{C} 4$ plant expansion in the Himalayan foreland and Arabian Peninsula. Geology, 2007, 35: 531-534

33 Qiang X, An Z, Song Y, et al. New eolian red clay sequence on the western Chinese Loess Plateau linked to onset of Asian desertification about $25 \mathrm{Ma}$ ago. Sci China Earth Sci, 2011, 54: 136-144

34 Sun J M, Ye J, Wu W Y, et al. Late Oligocene-Miocene mid-latitude aridification and wind patterns in the Asian interior. Geology, 2010, 38: 515-518

35 Wang P X, Neogene stratigraphy and paleoenvironments of China. Palaeogeogr Palaeoclimatol Palaeoecol, 1990, 77: 315-334

36 Liu T S, Zheng M P, Guo Z T. Initiation and evolution of the Asian monsoon system timely coupled with the ice-sheet growth and the tectonic movements in Asia (in Chinese). Quat Sci, 1998, 3: 194-204

37 Guo Z T, Sun B, Zhang Z S, et al. A major reorganization of Asian climate regime by the early Miocene. Clim Past, 2008, 4: 153-174

38 Sun Y B, An Z S. History and variability of Asian interior aridity recorded by eolian flux in the Chinese Loess Plateau during the past 7 Ma. Sci China Ser D: Earth Sci, 2002, 45: 420-429

39 Rea D K, Snoeckx H, Joseph L H. Late Cenozoic eolian deposition in the North Pacific: Asian drying, Tibetan up lift and cooling of the Northern Hemisphere. Paleoceanography, 1998, 13: 215-224

40 Burbank D W, Derry L A, France-Lanord C. Reduced Himalayan sediment production $8 \mathrm{Myr}$ ago despite an intensified monsoon. Nature, 1993, 364: 48-54

41 Qiang X K, Li Z X, Powell C McA, et al. Magnetostratigraphic record of the Late Miocene onset of the East Asian monsoon, and Pliocene uplift of northern Tibet. Earth Planet Sci Lett, 2001, 187: 83-93

42 An Z S, Zhang P Z, Wang E, et al. Changes of the monsoon-arid environment in china and growth of the Tibetan Plateau since the Miocene (in Chinese). Quat Sci, 2006, 26: 678-693

43 Bolin B. On the influence of the earth's orography on the westerlies. Tellus, 1950, 2: 184-195

44 Ye D Z. Effect of Tibet Plateau on the seasonal change of the atmospheric circulation (in Chinese). Acta Meteorol Sin, 1952, 22: 33-47

45 Flohn H. Large-scale aspects of the "summer monsoon" in South and East Asia. J Meteorol Soc Jpn, 1957, 35: 180-186

46 Mintz Y. Very long-term global integration of the primitive equations of atmospheric motion. WMO Tech Note No. 66, 1965, 141-167

47 Kasahara A, Sasamori T, Washington W M. Simulation experiments with a 12-layer stratospheric global circulation model. I. Dynamical effect of the Earth's orography and thermal influence of continentality. J Atmos Sci, 1973, 30: 1229-1251

48 Manabe S, Terpstra T B. The effects of mountains on the general circulation of the atmosphere as identified by numerical experiments. 
J Atmos Sci, 1974, 31: 3-42

49 Hahn D G, Manabe S. The role of mountains in the south Asian monsoon circulation. J Atmos Sci, 1975, 32: 1515-1541

50 Qian Y F, Yan H, Wang Q Q, et al. Numerical Study of Topographic Effects in Planetary Atmosphere. Beijing: Science Press, 1988. 1-217

51 Kutzbach J E, Guetter P J, Ruddiman W F, et al. Sensitivity of climate to late Cenozoic uplift in southern Asia and the American West: Numerical experiments. J Geophys Res, 1989, 94: 18393-18407

52 Ruddiman W F, Kutzbach J E. Late Cenozoic plateau uplift and climate change. Transaction of the Royal Society. Edinburgh: Earth Sci, 1990, 81: 301-314

53 Manabe S, Broccoli A J. Mountains and arid climates of middle latitudes. Science, 1990, 247: 192-194

54 Broccoli A J, Manabe S. The effects of orography on midlatitude northern hemisphere dry climates. J Clim, 1992, 5: 1181-1201

55 Qian Z A, Wu T W, Lu S H, et al. Numerical simulation of northwest china arid climate formation-Effects of the Qinghai-Xizang Plateau terrain and circulation field (in Chinese). Chin J Atmos Sci, 1998, 22: 753-762

56 Sato T, Kimura F. Impact of diabatic heating over the Tibetan Plateau on subsidence over northeast Asian arid region. Geophys Res Lett, 2005, 32: L05809

57 Raymo M E, Ruddiman W F. Tectonic forcing of late Cenozoic climate. Nature, 1992, 359: 117-122

58 Huber M, Goldner A. Eocene monsoons. J Asian Earth Sci, 2012, 44: 3-23

59 Ramstein G, Fluteau F, Besse J, et al. Effect of orogeny, plate motion and land-sea distribution on Eurasian climate change over the past 30 million years. Nature, 1997, 386: 788-795

60 Zhang Z S, Wang H J, Guo Z T, et al. What triggers the transition of palaeoenvironmental patterns in China, the Tibetan Plateau uplift or the Paratethys Sea retreat? Palaeogeogr Palaeoclimatol Palaeoecol, 2007, 245: 317-331

61 Henrot A J, Francois L, Favre E, et al. Effects of $\mathrm{CO}_{2}$, continental distribution, topography and vegetation changes on the climate at the Middle Miocene: A model study. Clim Past, 2010, 6: 675-694

62 Herold N, Huber M, Müller R D. Modeling the Miocene Climatic Optimum. Part I: Land and Atmosphere. J Clim, 2011, 24: 63536372

63 Micheels A, Bruch A A, Uhl D, et al. A late Miocene climate model simulation with ECHAM4/ML and its quantitative validation with terrestrial proxy data. Palaeogeogr Palaeoclimatol Palaeoecol, 2007, 253: 251-270

64 Tang H, Micheels A, Eronen J, et al. Regional climate model experiments to investigate the Asian monsoon in the Late Miocene. Clim Past, 2011, 7: 847-868

65 Haywood A M, Dowsett H J, Otto-Bliesner B, et al. Model Intercomparison Project (PlioMIP): Experimental design and boundary conditions (Experiment 1). Geosci Model Dev, 2010, 3: 227-242

66 Zhong D L, Lin D. Rising process of the Qinghai-Xizang (Tibet) Plateau and its mechanism. Sci Chin Seri D, 1996, 39: 369-379

67 Tapponnier P, Xu Z Q, Roger F, et al. Geology - Oblique stepwise rise and growth of the Tibetan Plateau. Science, 2001, 294: 16711677

68 Mulch A, Chamberlain C P. The Rise and Growth of Tibet. Nature, 2006, 439: 670-671

69 Molnar P, Boos W R, Battisti D S. Orographic controls on climate and paleoclimate of Asia: Thermal and mechanical roles for the Tibetan Plateau. Ann Rev Earth Planet Sci, 2010, 38: 77-102

70 Abe M, Kitoh A, Yasunari T. An evolution of the Asian summer monsoon associated with mountain uplift - Simulation with the MRI atmosphere-ocean coupled GCM. J Meteorol Soc Jpn, 2003, 81: 909-933

71 Chung S, Lo C H, Lee T Y, et al. Diachronous uplift of the Tibetan plateau starting 40 Myr ago. Nature, 1998, 394: 769-773

72 Wang G C, Zhang K X, Cao K, et al. Expanding processes of the Qinghai-Tibet Plateau during Cenozoic: An insight from spatiotemporal difference of uplift (in Chinese). Earth Sci (J Chin Univ Geosci), 2010, 35: 713-727
73 Zheng H, Powell C, An Z, et al. Pliocene up lift of the northern Tibetan Plateau. Geology, 2000, 28: 715-718

74 Fang X, Zhang W, Meng Q, et al. High resolution magnetostratigraphy of the Neogene Huaitoutala section in the eastern Qaidam Basin on the NE Tibetan Plateau, Qinghai Province, China and its implication on tectonic uplift of the NE Tibetan Plateau. Earth Planet Sci Lett, 2007, 258: 293-306

75 Chakraborty A, Nanjundiah R S, Srinivasan J. Role of Asian and African orography in Indian summer monsoon. Geophys Res Lett, 2002, 29: 1989

76 Zhang R, Liu X D. The effects of tectonic uplift on the evolution of Asian summer monsoon climate since Pliocene (in Chinese). Chin J Geophys, 2010, 53: 2817-2828

77 Wu G X, Liu Y M, He B, et al. Thermal controls on the Asian summer monsoon. Sci Rep, 2012, 2: 404

78 Zhang R, Jiang D B, Liu X D, et al. Modeling the climate effects of different subregional uplifts within the Himalaya-Tibetan Plateau on Asian summer monsoon evolution. Chin Sci Bull, 2012, 57: 46174626

79 Tang H, Micheels A, Eronen J T, et al. Asynchronous responses of East Asian and Indian summer monsoons to mountain uplift shown by regional climate modelling experiments. Clim Dyn, 2013, 40: 1531-1549

80 Boos W R, Kuang Z M. Sensitivity of the South Asian monsoon to elevated and non-elevated heating. Sci Rep, 2013, 3: 1192

81 Chakraborty A, Nanjundiah R S, Srinivasan J. Theoretical aspects of the onset of Indian summer monsoon from perturbed orography simulations in a GCM. Ann Geophys, 2006, 24: 2075-2089

82 Jin Q H, He J H, Chen L X, et al. Impacts of ocean-land distribution over the Southern Asia and the continents over the southern hemisphere on the formation of Asian summer monsoon circulation (in Chinese). Chin J Atmos Sci, 2006, 30: 1043-1053

83 Yanai M, Wu G X. 2006. Effects of the Tibetan Plateau. In: Wang B, ed. The Asian Monsoon. Berlin: Springer, 2006. 513-549

84 Rea D K. The paleoclimatic record provided by eolian deposition in the deep sea: The geologic history of wind. Rev Geophys, 1994, 32: $159-195$

85 Duce R A. Sources, distributions, and fluxes of mineral aerosols and their relationship to climate. In: Charlson R, Heintzenberg J, eds. Aerosol Forcing of Climate. New York: Wiley, 1995. 43-72

86 Chen J, Li G J. Geochemical studies on the source region of Asian dust. Sci China Earth Sci, 2011, 54: 1279-1301

87 Windley F F, Allen M R. Mongolian Plateau: Evidence for a late Cenozoic mantle under Central Asia. Geology, 1993, 21: 295-298

88 Prell W L, Kutzbach J E. Sensitivity of the Indian monsoon to forcing parameters and implications for its evolution. Nature, 1992, 360: $647-652$

89 Qian Y, Qian Y F. The sensitivity experiments of influences of uplift of Tibetan Plateau on circulation in summer (in Chinese). Acta Meteorol Sin, 1996, 54: 474-483

90 Dirmeyer P A. Land-sea geometry and its effect on monsoon circulations. J Geophys Res, 1998, 103: 11555-11572

91 Chou C. Land-sea heating contrast in an idealized Asian summer monsoon. Clim Dyn, 2003, 21: 11-25

92 Wu G X, Liu Y, Zhu X, et al. Multi-scale forcing and the formation of subtropical desert and monsoon. Ann Geophys, 2009, 27: 36313644

93 Chen T C. Maintenance of summer monsoon circulations: A planetary perspective. J Clim, 2003, 16: 2022-2037

94 Chao W C, Chen B D. The origin of monsoon. J Atmos Sci, 2001, 58: 3497-3507

95 Lu H Y, Wang X, Li L. Aeolian sediment evidence that global cooling has driven late Cenozoic stepwise aridification in central Asia. Geol Soc Lond Spec Publ, 2010, 342: 29-44

96 Liu X D, Li L, An Z S. Tibetan Plateau uplift and drying in Eurasian interior and Northern Arfica (in Chinese). Quat Sci, 2001, 21: 114-122

97 Miao Y F, Herrmann M, Wu F L, et al. What controlled Mid-Late Miocene long-term aridification in Central Asia? - Global cooling or Tibetan Plateau uplift: A review. Earth-Sci Rev, 2012, 112: 155-172 
98 Zhang L Y. The influence of the uplift of Qinghai-Xizang Plateau on the Quaternary environmental evolution in China (in Chinese). J Lanzhou Univ (Nat Sci). 1981, 3: 142-155

99 Shi Y F, Tang M C, Ma Y Z. Linkage between the second uplifting of the Qinghai-Xizang (Tibetan) Plateau and the initiation of the Asian monsoon system. Sci China Ser D: Earth Sci, 1999, 42: 303-312

100 Lunt D J, Flecker R, Clift P D. The impacts of Tibetan uplift on palaeoclimate proxies. Geol Soc Lond Spec Publ, 2010, 342: 279-291

101 Bush A B G. A positive climatic feedback mechanism for Himalayan glaciation. Quat Intern, 2000, 65/66: 3-13

102 Rosenfeld D, Rudich Y, Lahav R. Desert dust suppressing precipitation: A possible desertification feedback loop. Proc Natl Acad Sci USA, 2001, 98: 5975-5980

103 Jickells T D, An Z S, Andersen K K, et al. Global iron connections between desert dust, ocean biogeochemistry, and climate. Science, 2005, 308: 67-71

104 Liu X D, Tang M C. On the critical height of the effect of Qing-
hai-Xizang Plateau uplift on the atmosphere (in Chinese). Plateau Meteorol, 1996, 15: 131-140

105 Prell W, Kutzbach J E. The impact of Tibet-Himalayan elevation on the sensitivity of the monsoon climate system to changes in solar radiation. In: Ruddiman W, ed. Tectonic Uplift and Climate Change. New York: Plenum Publishing Corporation, 1997. 171-201

106 Liu X D, Kutzbach J E, Liu Z, et al. The Tibetan Plateau as amplifier of orbital-scale variability of the East Asian monsoon. Geophys Res Lett, 2003, 30: 1839

107 Zhang P Z, Molnar P, Downs W R, et al. Increased sedimentation rates and grain sizes 2-4 Myr ago due to the influence of climate change on erosion rates. Nature, 2001, 410: 891-897

108 Rowley D B, Garzione C N. Stable isotope-based paleoaltimetry. Ann Rev Earth Planet Sci, 2007, 35: 463-508

109 Park H S, Chiang J C H, Bordoni S. The mechanical impact of the Tibetan Plateau on the seasonal evolution of the south Asian monsoon. J Clim, 2012, 25: 2394-2407

Open Access This article is distributed under the terms of the Creative Commons Attribution License which permits any use, distribution, and reproduction in any medium, provided the original author(s) and source are credited. 